\title{
Substance P Induced by Peripheral Nerve Injury in Primary Afferent Sensory Neurons and Its Effect on Dorsal Column Nucleus Neurons
}

\author{
Koichi Noguchi, ${ }^{1}$ Yoshinori Kawai, ${ }^{2}$ Tetsuo Fukuoka, ${ }^{1}$ Emiko Senba, ${ }^{2}$ and Kenji Miki ${ }^{1}$ \\ ${ }^{1}$ Department of Anatomy and Neuroscience, Hyogo College of Medicine, Hyogo 663, Japan, and 'Department of \\ Anatomy and Neurobiology, Wakayama Medical College, Wakayama 640, Japan
}

Using in situ hybridization and the retrograde tracer, Fluorogold, we examined the expression of preprotachykinin (PPT) MRNA in the rat dorsal root ganglion neurons projecting to the gracile nucleus. Seven days after unilateral sciatic nerve transection, some medium- to large-sized neurons in the rat dorsal root ganglia projecting to the gracile nucleus express PPT mRNA, whereas very few gracile nucleus-projecting neurons on the contralateral side express PPT mRNA. Immunohistochemistry revealed an increase in substance $P$ (SP) immunoreactivity in the gracile nucleus and large myelinated fibers in the dorsal root 2 weeks after unilateral sciatic nerve transection. The results suggest that medium to large DRG cells that project to the gracile nucleus express PPT mRNA de novo in response to peripheral nerve injury, and increased SP is transported to the gracile nucleus through large myelinated fibers. To determine whether the increased SP might affect the excitability of the gracile nucleus neurons postsynaptically, Fos expression after electrical stimulation of the injured sciatic nerve was examined. Multiple injections of the NK-1 receptor antagonist, CP-96,345, suppressed stimulus-induced Fos expression in gracile nucleus neurons including thalamic relay neurons. The inactive enantiomer, CP-96,344, had no effect on stimulus-induced Fos expression. These data indicate that the de novo synthesized SP in the lesioned primary afferent neurons may be involved in an augmentation of excitability in the dorsal column-medial lemniscus sensory pathway. This hyperexcitability may play a role in the pathogenesis of abnormal neuropathic sensations following peripheral nerve injury.

[Key words: dorsal root ganglion, preprotachykinin mRNA, substance $P$, nerve injury, gracile nucleus, $\mathbf{N K - 1}$ receptor antagonist]

Peripheral nerve injury in humans may lead to abnormal pain sensations and other sensory abnormalities. Although it is thought that alterations in central neuronal processing play an

\footnotetext{
Received Apr. 20, 1995; revised July 5, 1995; accepted July 25, 1995

We gratefully acknowledge the donation of peptide antagonist from Pfizer Inc. (Groton, CT) and antibody from Dr. P. W. Mantyh. We thank Dr. G. J Bennett for careful reading of the manuscript. This work was supported in part by the Ministry of Education, Science and Culture of Japan, the Mochida Memorial Foundation and the Uehara Memorial Foundation.

Correspondence should be addressed to Koichi Noguchi, M.D., Ph.D., Department of Anatomy and Neuroscience, Hyogo College of Medicine, $1-1 \mathrm{Mu}-$ kogawa-cho, Nishinomiya, Hyogo 663, Japan.

Copyright $(1995$ Society for Neuroscience $0270-6474 / 95 / 157633-11 \$ 05.00 / 0$
}

important role in the development of such pathological pain, a key mechanism, viz., how injured primary afferents contribute to abnormality in the sensory pathway, is not fully understood (Woolf, 1983, 1992; Basbaum et al., 1992; Gracely et al., 1992; Coderre et al., 1993; Wiesenfeld-Hallin et al., 1993; Thompson et al., 1994). One possible mechanism whereby primary afferents might influence spinal or supraspinal sites following peripheral nerve injury is a change in the expression of neuropeptides (Hökfelt et al., 1994). In the spinal cord, substance P (SP) appears to be involved in the mechanism of hyperexcitability of dorsal horn neurons via a direct action on the postsynaptic cells or via potentiation of the excitatory effects of glutamate (Kangrga and Randic, 1990; De Koninck and Henry, 1991; Haley and Wilcox, 1992; Levine et al., 1993). Neurons containing SP as well as other neuropeptides exhibit changes in gene expression and peptide levels in the dorsal root ganglia (DRG) and the spinal cord dorsal horn after axotomy. It has been shown that both mRNA and peptide levels of SP, somatostatin, and calcitonin gene-related peptide (CGRP) in the DRG decrease after axotomy (Jessel et al., 1979; Nielsch et al., 1987; Noguchi et al., 1989, 1990, 1993; Henken et al., 1990; Baranowski et al., 1993), whereas the levels of galanin, vasoactive intestinal polypeptides, and neuropeptide $\mathrm{Y}$ are induced (Shehab and Atkinson, 1986; Hökfelt et al., 1987; Villar et al., 1989; Noguchi et al., 1989, 1993; Wakisaka et al., 1991, 1992). It seems likely that the downregulation of SP and CGRP will attenuate the transmission of peptide-related information at the first synapse in the dorsal horn (Hökfelt et al., 1994). However, more recently, we have demonstrated that some large- and medium-sized DRG cells are labeled for PPT mRNA, whereas PPT mRNA in small DRG cells are depressed, following peripheral nerve transection (Noguchi et al., 1994). Parallel changes in SP immunoreactivity (SPir) are present in sirnilarly sized populations of DRG neurons. The present study was initiated to further characterize these large DRG neurons labeled for PPT mRNA after axotomy.

DRG neuronal size is correlated with the caliber of primary afferent axons, and normally tachykinin peptides, SP in particular, are localized to small neurons, which are usually associated with unmyelinated axons (Willis and Coggeshall, 1991). These axons terminate mainly in superficial laminae $I$ and II of the spinal dorsal horn and carry information from peripheral nociceptors. Medium and large cells in the DRG have myclinated axons that carry information from low-threshold mechanoreceptors and terminate mainly in laminae III and IV of the spinal dorsal horn and dorsal column nuclei of the medulla oblongata (Brown, 1981; Willis and Coggeshall, 1991). In this article, we 

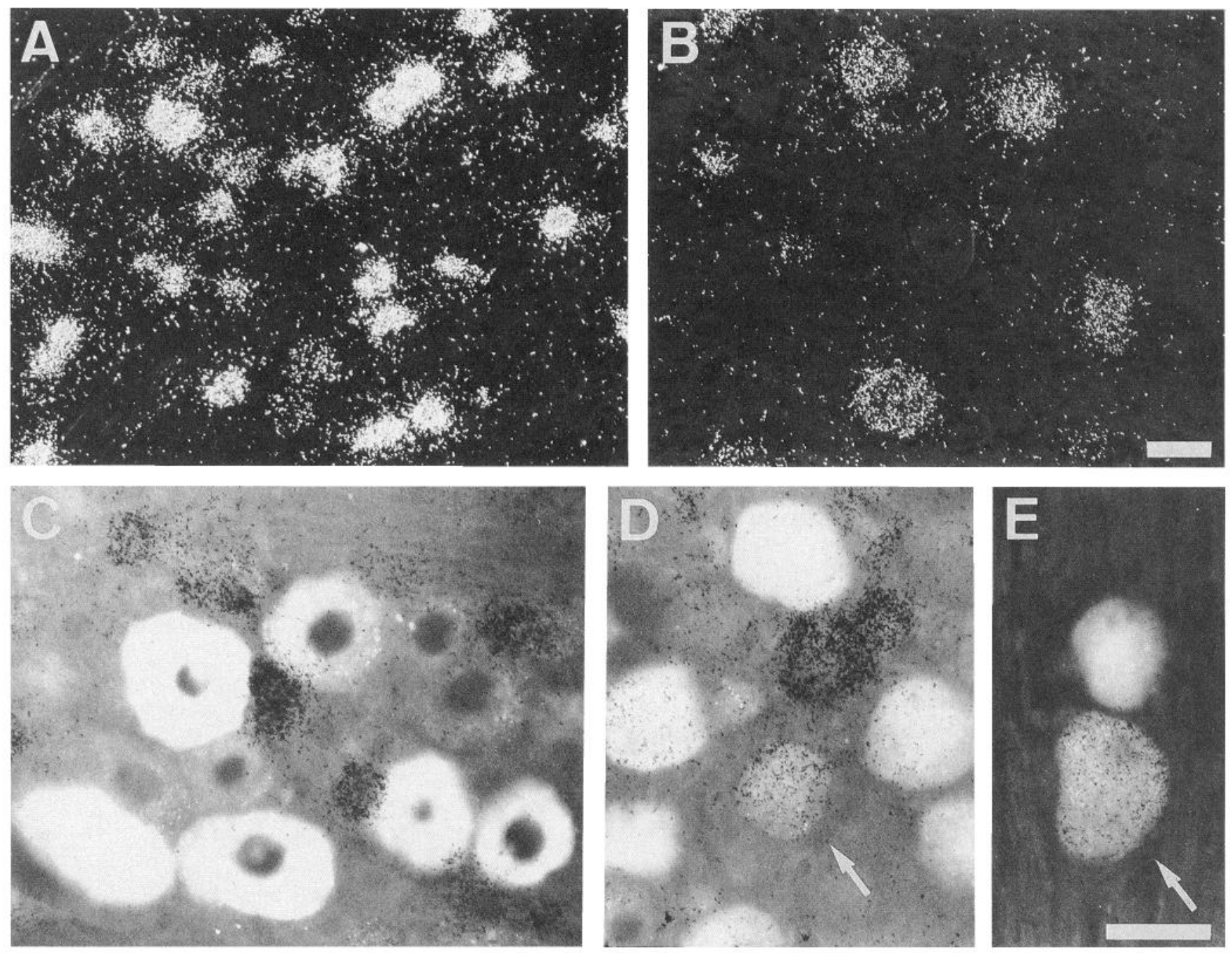

Figure 1. $A$ and $B$, Dark-field photomicrographs showing the distribution of PPT mRNA in $A$ contralateral and $(B)$ lesioned L5 DRGs. Animals received a transection of the L5 spinal nerve $7 \mathrm{~d}$ previously. Note that several large cells in the lesioned DRG expressed PPT mRNA $(B)$, while the number and signal intensity of small neurons expressing PPT mRNA were clearly decreased as compared with control DRG ( $A$ ). $C-E$, Demonstration of DRG neurons projecting to the gracile nucleus labeled for PPT mRNA by in situ hybridization and the retrogradely transported tracer, Fluorogold. Animals received a $(C)$ sham operation or $(D$ and $E)$ transection of the L5 spinal nerve. Arrows $(D$ and $E)$ indicate medium- or large-size cells showing double labeling with PPT mRNA and Fluorogold. Scale bars $(A-E), 50 \mu \mathrm{m}$.

describe an increase in SPir in the gracile nucleus and in large myelinated fibers in the dorsal root after peripheral axotomy. Moreover, the effect of increased SP in the gracile nucleus on neuronal excitability after axotomy was examined using an NK-1 receptor antagonist and Fos expression induced by electrical stimulation to the injured nerve.

\section{Materials and Methods}

Animal procedures. Male Sprague-Dawley rats (200-250 gm) were used in this study. Two types of peripheral nerve axotomy operations were performed (Noguchi et al., 1993, 1994). Under deep anesthesia (sodium pentobarbital, $50 \mathrm{mg} / \mathrm{kg}$, i.p.), the left spinal nerve (L5) of one group of animals was exposed and cut at its exit from the intervertebral foramen, a few millimeters distal to the DRG. The completeness of the transection was assessed after the animals were sacrificed. A second group of animals received a ligation and transection of the left sciatic nerve at the level of the upper thigh. Naive animals and sham-operated animals were used as controls. The animals were allowed to survive for 1 to $28 \mathrm{~d}$.

In situ hybridization with retrograde tracer, Fluorogold. Animals were anesthetized with sodium pentobarbital $(50 \mathrm{mg} / \mathrm{kg}$, i.p. $)$ and re- ceived an injection of $1.0 \mu \mathrm{l}$ of $2 \%$ Fluorogold (Fluorochrome, $\mathrm{CO}$ ) in saline into the left gracile nucleus. Animals received a L5 spinal nerve transection or a sham operation $7 \mathrm{~d}$ after Fluorogold injection. Seven days later ( $14 \mathrm{~d}$ after Fluorogold injection), the animals were terminally anesthetized and perfused with $4 \%$ paraformaldehyde in $0.1 \mathrm{M}$ phosphate buffer (PB) (pH 7.4). The L5 DRGs were dissected out and postfixed overnight in the same fixative followed by immersion in $20 \%$ sucrose in PB for cryoprotection. After a few days the tissue was frozen with powdered dry ice, cut transversely with a cryostat at $16 \mu \mathrm{m}$ thickness, thaw mounted onto Silane (Sigma, St. Louis, MO)-coated slides, and stored at $-80^{\circ} \mathrm{C}$ until ready for use. To begin the in situ hybridization, tissue sections were digested with proteinase $\mathrm{K}(1 \mathrm{mg} / \mathrm{ml})(\mathrm{Sig}-$ $\mathrm{ma}$ ) at $37^{\circ} \mathrm{C}$ for $30 \mathrm{~min}$ in $0.1 \mathrm{M}$ Tris containing $0.05 \mathrm{M}$ ethylenediamine tetra-acetic acid $(\mathrm{pH} 8.0)$, rinsed briefly in distilled water followed by $0.1 \mathrm{M}$ triethanolamine (TEA) $(\mathrm{pH} 8.0)$, acetylated with $0.25 \%$ acetic acid ( $\mathrm{pH} 8.0$ ), and dehydrated through graded ethanols. The hybridization was performed overnight at $37^{\circ} \mathrm{C}$ in a buffer containing $4 \times \mathrm{SSC}$, $50 \%$ formamide, $0.12 \mathrm{~m}$ phosphate buffer, $1 \times$ Denhardt's solution, $0.2 \%$ sodium dodecyl sulfate, $250 \mu \mathrm{g} / \mathrm{ml}$ yeast tRNA, $10 \%$ dextran sulfate, and $100 \mathrm{~mm}$ dithiothreitol with $10^{6} \mathrm{cpm}$ of labeled probe $/ 100 \mu \mathrm{l}$ buffer/ slide. The probe was labeled with ${ }^{35} S$-labeled deoxyadenosine $[\alpha$-thio] triphosphate (NEN) and terminal deoxynucleotidyltransferase (Takara, Shiga, Japan). The specific activity of the resultant probe was $8-15 \times$ 

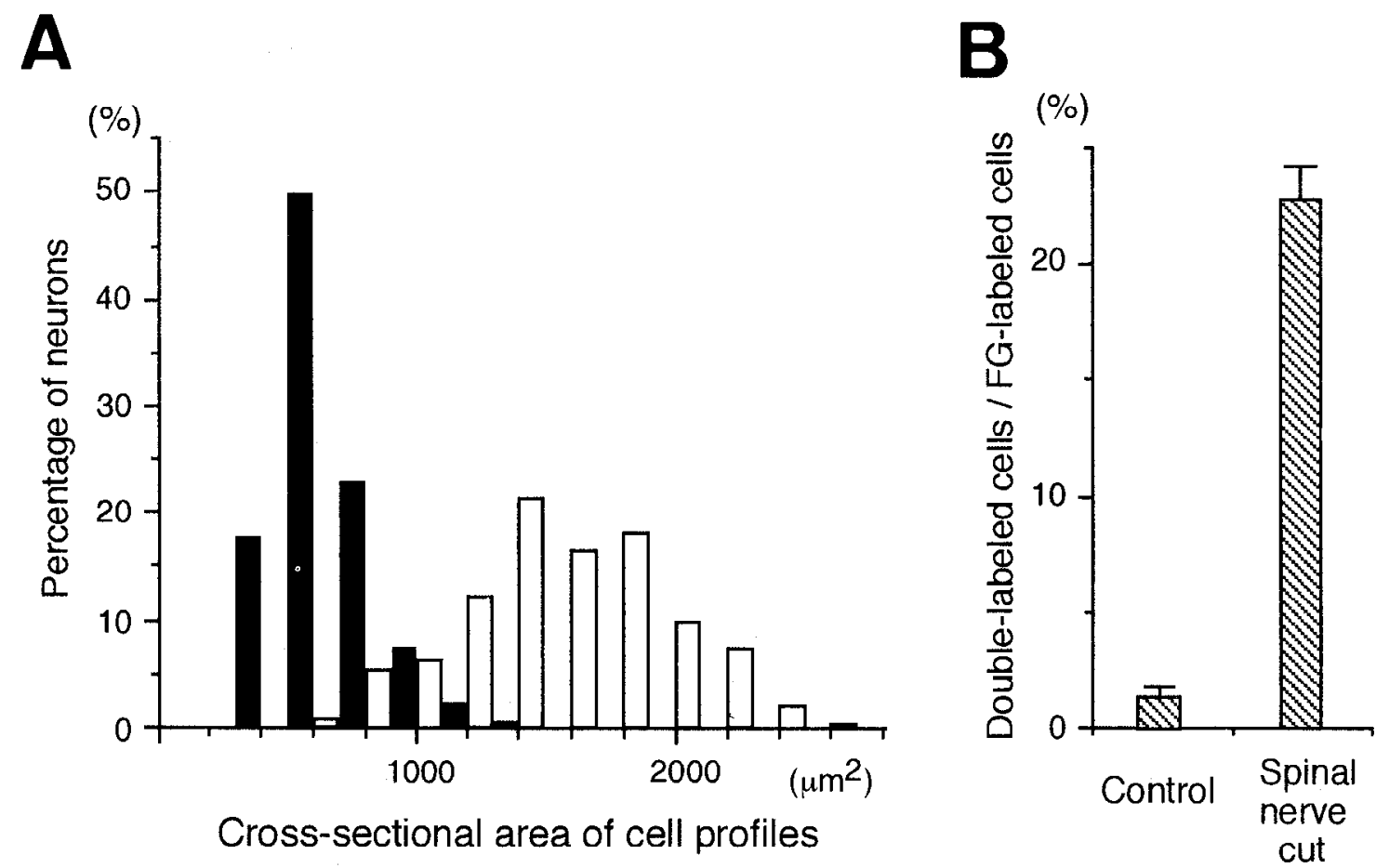

Figure 2. A, Cross-sectional areas of the lesioned L5 DRG neuronal profiles double labeled for PPT mRNA and Fluorogold (white columns; $n$ $=265,82-92$ cell profiles from each of three animals), together with nomal L5 DRG cell profiles expressing PPT mRNA (black columns; $n=$ 258 from three control animals). $B$, Percentage of Fluorogold (FG)-labeled neuronal profiles showing double labeling in control or lesioned DRGs. Bars indicate mean \pm SEM. Data were obtained from 16-19 sections from three animals of each group.

$10^{8} \mathrm{cpm} / \mu \mathrm{g}$. Following hybridization, the sections were washed four times for $15 \mathrm{~min}$ each at $55^{\circ} \mathrm{C}$ in $1 \times \mathrm{SSC}, 30 \mathrm{~min}$ at room temperature in $1 \times \mathrm{SSC}$, and briefly in $70 \%$ ethanol, and then dried. For autoradiography, the sections were coated with Ilford G-5 emulsion (Ilford; diluted 1:1 with distilled water at $40^{\circ} \mathrm{C}$ ) and exposed for $3-4$ weeks in light-tight boxes at $4^{\circ} \mathrm{C}$. After development in D19 (Kodak) and fixing in $24 \%$ sodium thiosulfate, the sections were rinsed in distilled water and coverslipped with glycerin-PBS. The oligonucleotide probe consisted of 48 bases complementary to bases $124-171$ of the $\beta$-preprotachykinin mRNA sequence (Krause, 1987). The specificity of the PPT oligonucleotide probe used in this study was confirmed in a previous report (Noguchi and Ruda, 1992).

Immunoelectronhistochemistry. Animals received a transection of the left L5 spinal nerve under deep anesthesia. Twelve days later, the L5 dorsal roots were exposed and ligated bilaterally to cause an accumulate of SP in the dorsal root fibers. Animals were perfused through the heart with $4 \%$ paraformaldehyde in $0.1 \mathrm{M} \mathrm{PB} 2 \mathrm{~d}$ after dorsal root ligation. Small pieces of dorsal root taken a few millimeters distal to the ligation were excised and postfixed overnight in the same fixative at $4^{\circ} \mathrm{C}$. They were then immersed in $30 \%$ sucrose in $0.1 \mathrm{M} \mathrm{PB}$ at $4^{\circ} \mathrm{C}$ for $2 \mathrm{~d}$. Cryostat sections were cut at a thickness of $50 \mu \mathrm{m}$. The sections were incubated at $4^{\circ} \mathrm{C}$ for $72 \mathrm{hr}$ in SP antiserum (1:5000; Incstar, Stillwater, MN). Then they were incubated overnight at $4^{\circ} \mathrm{C}$ in biotinylated IgG $(1: 200$; Vector, Burlingame, $\mathrm{C} \Lambda$ ). $\Lambda$ fter several rinses, they were incubated in avidinbiotin-horseradish peroxidase complex (1:200; Vector), and then reacted in diaminobenzidine tetrahydrochloric acid plus $\mathrm{H}_{2} \mathrm{O}_{2}$. The sections were fixed at room temperature for $1 \mathrm{hr}$ in $1 \% \mathrm{OsO}_{4}$ in $0.1 \mathrm{M} \mathrm{PB}$, dehydrated through graded ethanols, and embedded in Epon 812. Ultrathin sections were cut on a ultramicrotome (Sorvall, Norwalk, CT), collected on single-slot $(1 \times 2 \mathrm{~mm})$ grids, and stained with uranyl acetate $(10 \%$ in $50 \%$ ethanol) and lead citrate. They were observed in an electron microscope (JEOL 100C, Tokyo, Japan) operating at $80 \mathrm{kV}$.

Immunohistochemistry. Animals received a unilateral ligation and transection of the sciatic nerve at the midthigh level or a sham operation, and were sacrificed 4-28 d later by cardiac perfusion with $4 \%$ paraformaldehyde in $0.1 \mathrm{M} \mathrm{PB}$. The medulla oblongata and L4-5 spinal cord were dissected out, postfixed 1-2 $d$ in the same fixative, and then transferred to $20 \%$ sucrose in PB for cryoprotection. Tissue was cut with a cryostat at $30 \mu \mathrm{m}$ and processed for immunohistochemistry for $\mathrm{SP}, \mathrm{Fos}$, or SP receptor (SPR) using the avidin-biotin complex (ABC) method, as described elsewhere (Noguchi et al., 1994). Briefly, tissue sections were incubated in polyclonal antiserum to SP, Fos (Ab-2, Oncogene Science, Manhasset, NY) or SPR (kindly donated by Dr. Mantyh) for $2 \mathrm{~d}$ at $4^{\circ} \mathrm{C}$, followed by incubation in biotinylated anti-rabbit antibody (1:200; Vector) for $60 \mathrm{~min}$ at room temperature. Following incubation in $\mathrm{ABC}$ solution (Vector) for $60 \mathrm{~min}$ at room temperature, the sections were rinsed and reacted with $0.05 \% 3,3^{\prime}$-diaminobenzidine tetrahydrochloride (DAB, Sigma) in the presence of $0.01 \%$ hydrogen peroxide $(6-12 \mathrm{~min})$. Tissue sections were then washed, mounted on slides, dried, and coverslipped.

In order to induce Fos in the gracile nucleus, bilateral electrical stimulation to the sciatic nerves, just distal to the level of the hip joint, was delivered (10 min pulse train of $5 \mathrm{~Hz}$; pulses: $0.5 \mathrm{msec}, 0.1 \mathrm{~mA}) 2 \mathrm{hr}$ before sacrifice. Since there was considerable heterogeneity of labeling for SP and Fos within the rostrocaudal extent of the gracile nucleus, we used every second section ( $30 \mu \mathrm{m}$ thick) from $300 \mu \mathrm{m}$ rostral to the obex to $300 \mu \mathrm{m}$ caudal to it; labeling was most conspicuous in this region.

In the double-labeling experiment, Fluorogold ( $1.0 \mu 1$ of $2 \%$ solution) was injected into the VPL nucleus contralateral to the side of the nerve lesion $10 \mathrm{~d}$ after sciatic nerve transection. Four days later, animals were sacrificed $2 \mathrm{hr}$ after electrical stimulation and immunohistochemistry for Fos was performed.

$N K-I$ receptor antagonist. In order to examine the effect of increased $\mathrm{SP}$ on cellular activity in the gracile nucleus, two methods of application of the NK-1 antagonist were used before electrical stimulation and immunohistochemistry for $c$-fos. According to the first method, animals $(100-150 \mathrm{gm})$ received injections of saline, CP-96,345, or CP-96,344 (each $5 \mathrm{mg} / \mathrm{kg}$, s.c.; Pfizer) $30 \mathrm{~min}$ before electrical stimulation of the sciatic nerve (single injection group). CP-96,345 is a nonpeptide antagonist of the NK1 receptor and CP-96,344 is its inactive enantiomer (Snider et al., 1991). According to the second method, animals received injections of saline or CP-compounds $30 \mathrm{~min}$ prior to, and every $12 \mathrm{hr}$ after, unilateral transection of the sciatic nerve for 1 week, with the final injection given $30 \mathrm{~min}$ before electrical stimulation of the sciatic nerve (periodic injections group). Electrical stimulation and processing of tissue were as described above.

Quantification. Background density of silver grains was obtained for each section from $2010 \mu^{2}$ areas of emulsion away from labeled neurons. These values were $1.1-1.5$ grains $/ 10 \mu \mathrm{m}^{2}$. Neurons with grain 


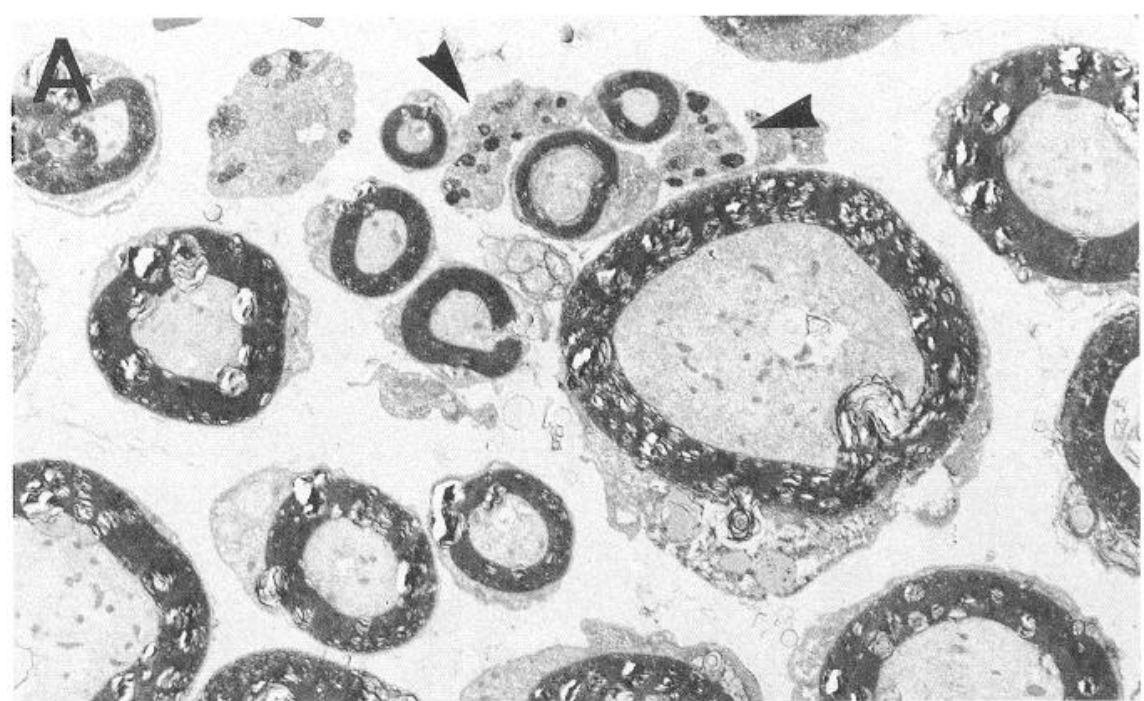

Figure 3. $A$ and $B$, Immunoelectron microscopy of the L5 dorsal root on the side contralateral $(A)$ and ipsilateral $(B)$ to transection of the L5 spinal nerve. $C$, Light photomicrograph of the same area of the L5 dorsal root as shown in $B$. Note SPir in a large myelinated fiber ( $B$ and $C$, arrows). The contralateral dorsal root contained SPir only in unmyelinated fibers (A, arrowheads). A marked collapse of the myelin sheath, an expected transganglionic change, was observed $(B$, white arrow). Scale bars, $5 \mu \mathrm{m}(A$ and $B), 10 \mu \mathrm{m}(C)$.

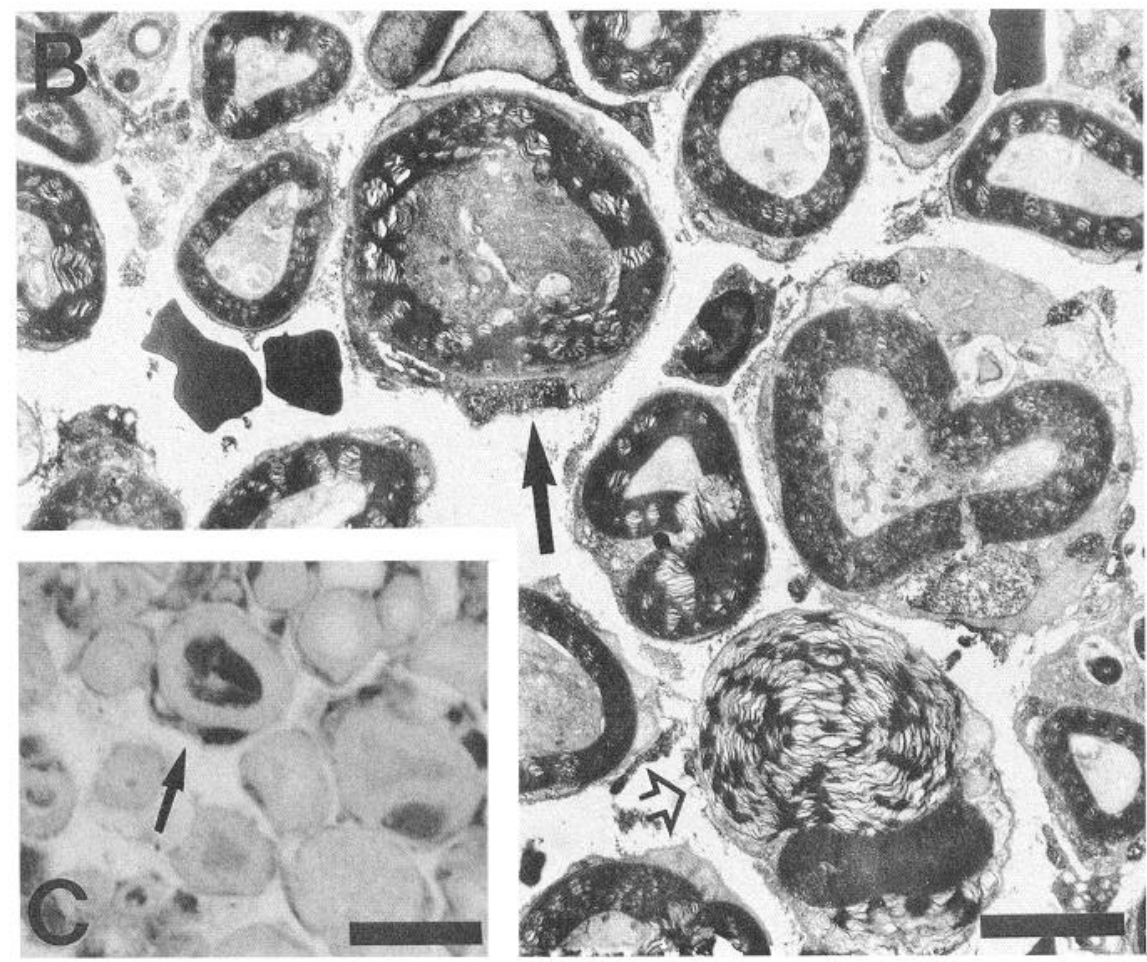

densities at least five times higher than the background densities were considered positively labeled. Cross-sectional areas of cell profiles were obtained using a computer-based image analysis system (IBAS, Zeiss). Neurons with a visible nucleus in every third $10 \mu \mathrm{m}$ section of the L5 DRG were measured. Since a stereological approach was not used in this study, quantification of the data may represent a biased estimate of the actual numbers of neurons.

To determine changes in SPir and SPR immunoreactivity (SPRir) in the gracile nucleus, the density of SPir was quantified using an IBAS image-analysis system. While viewing the monitor, upper and lower thresholds of gray level density were set such that only specific SP immunoreaction product was accurately discriminated from the background in the outlined gracile nucleus, and read pixel by pixel by the computer. Subsequently, area of each discriminated structures was measured, which was divided by the area of outlined gracile nucleus. Percentages of the discriminated areas in the gracile nucleus were compared between the operated and sham-operated sides. Change in SPir in laminae III-IV of the spinal cord was quantified by the same method that was used for the gracile nucleus.

The number of neurons with Fos immunoreactivity (Fos-ir) in the gracile nucleus and laminae III-IV of the spinal cord ipsilateral and contralateral to operation were counted in randomly selected sections $(N=3$ rats per treatment group at each time point, $15-20$ sections per rat). Pair-wise comparison ( $t$ test) was used to determine ipsilateral versus sham-operated differences. An analysis of variance compared the number of Fos-ir neurons with visible nuclei ipsilateral to the operation (mean number of neurons per section in each animal) in the CP-96,345, CP-96,344, and saline-treated animals.

\section{Results}

$P P T$ mRNA in DRG neurons projecting to the gracile nucleus In ipsilateral DRGs of rats that received spinal nerve transection $7 \mathrm{~d}$ previously, the overall level of PPT mRNA signal was clearly decreased, but some medium- and large-sized cells were labeled for PPT mRNA (Fig. 1B), in contrast to the intense constitutive expression of PPT mRNA in mainly small DRG cells (Fig. 1A) (Noguchi et al., 1994).

In experiments using in situ hybridization with fluorogold in- 

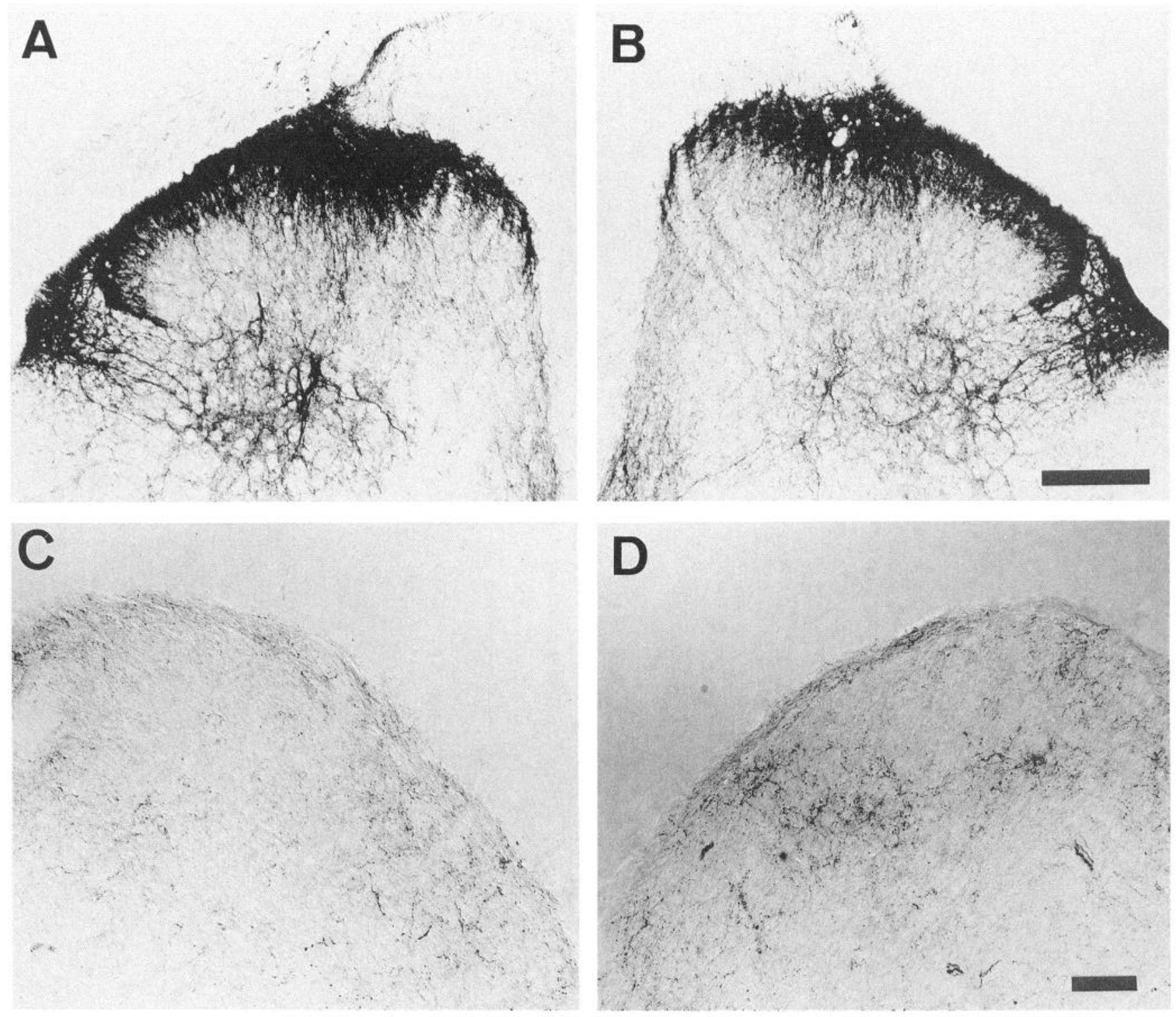

Figure 4. $A$ and $B$, Photomicrographs showing SPir in the L5 spinal cord $(A$ and $B)$ and the gracile nucleus $(C$ and $D)$ of rats that had received a unilateral transection of the sciatic nerve $14 \mathrm{~d}$ previously. In the spinal cord $(A$ and $B)$, there was no consistent increase in SPir in any lamina of the dorsal horn. In the gracile nucleus $(C$ and $D)$, SPir in fibers and terminals on the lesioned side $(D)$ was increased, as compared with the contralateral side $(C)$. Scale bars: $A$ and $B, 200 \mu \mathrm{m} ; C$ and $D, 50 \mu \mathrm{m}$.

jected into the gracile nucleus, a number of medium- (Fig. 1D) and large-sized (Fig. $1 E$ ) neurons were seen that expressed both PPT mRNA and Fluorogold-label on the nerve-lesioned side. Very few neurons showed double labeling in control DRGs (Fig. $1 C)$. The double-labeled cells were larger than the neurons showing constitutive expression of PPT mRNA (Fig. 2A); large double-labeled cells were detectable exclusively in lesioned DRGs (Fig. 2B).

The average cross-sectional area of Fluorogold-labeled cell profiles expressing PPT mRNA (double-labeled cells) in the ipsilateral DRG was $1554 \pm 24 \mu^{2}$, in contrast, that of PPT mRNA-labeled cells in control DRG was $657 \pm 11 \mu \mathrm{m}^{2}$. The cell size distribution in lesioned DRGs did not show any tendency for increased cell size. These data indicate that mediumto large-sized DRG neurons that project to the gracile nucleus express PPT mRNA de novo in response to peripheral nerve injury, whereas the expression of PPT mRNA in small neurons is suppressed.

\section{Substance P immunoreactivity}

First, we examined the localization of substance P (SP) immunoreactivity, a common final product of the three PPT mRNAs (Krause et al., 1987), in dorsal root fibers. Some large myelinated fibers in the L5 dorsal root contained SPir 2 weeks after spinal nerve transection (Fig. 3B,C), whereas SPir was found mainly in unmyelinated fibers in control dorsal roots (Fig. 3A). The proximal branches of many lumbar DRG neurons are believed to reach to both the spinal dorsal horn and the gracile nucleus (Willis and Coggeshall, 1991). However, in L4-5 spinal cord, significant increase in SPir was not detected in any lamina of the dorsal horn on the lesioned side, although SPir in laminae I-II was decreased (Figs. $4 A, B$ ) following sciatic nerve transec- 

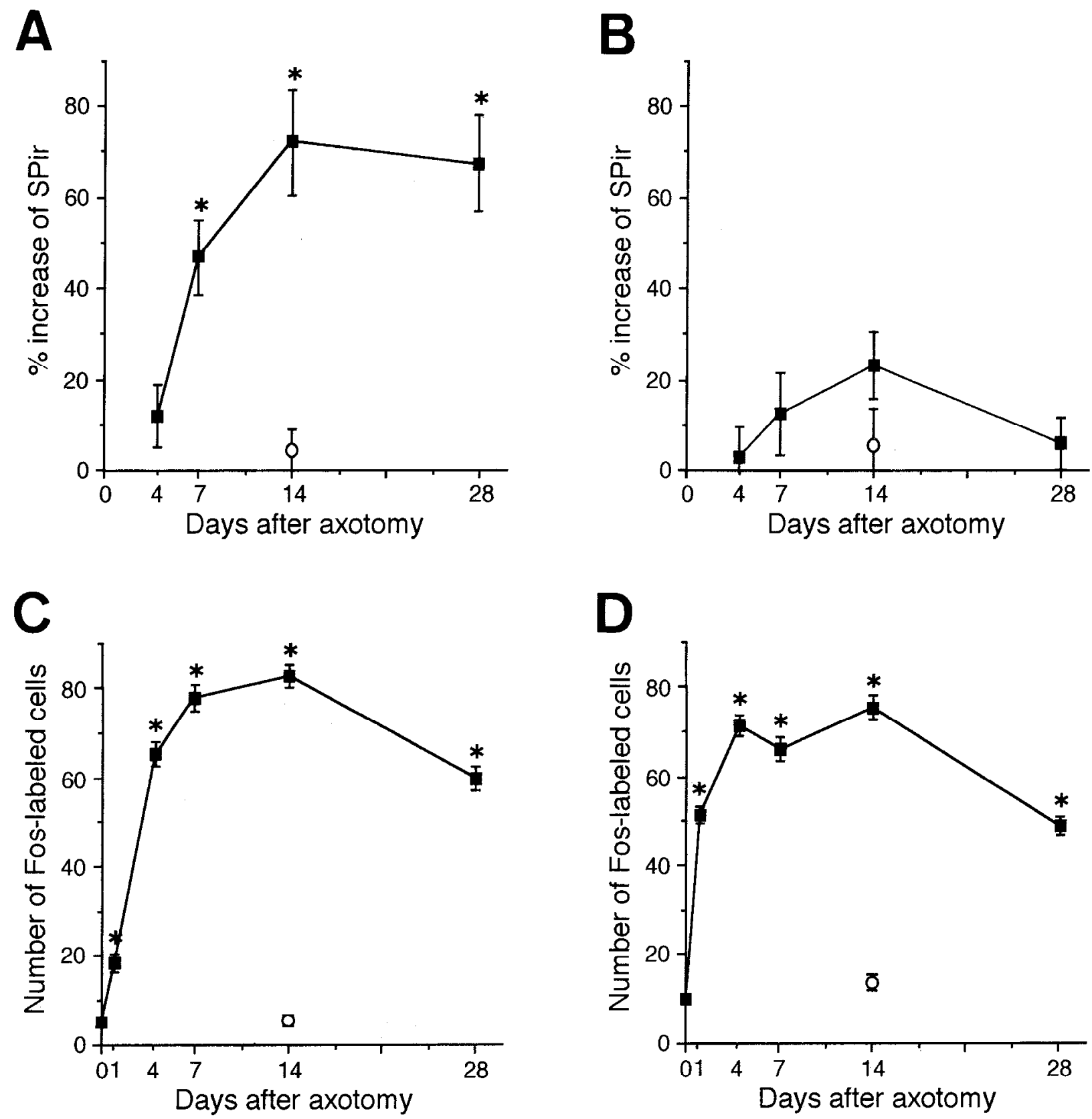

Figure 5. $A$ and $B$, Time course of the increase in SPir in the ipsilateral gracile nucleus $(A)$ and laminae III-IV of the L4-5 spinal cord $(B)$ after unilateral transection of the sciatic nerve (squares) or a sham operation (circle). The percent increase was obtained from the difference in labeling between the two sides, as measured by a computer-based image analysis system. Data are the mean \pm SEM (38-45 sections from three animals at each time point). $C$ and $D$, Time course of the number of Fos-labeled profiles in the ipsilateral gracile nucleus $(C)$ and laminae III-IV of the L45 spinal cord $(D)$ induced by electrical stimulation of the lesioned (squares) or sham-operated (circle) sciatic nerve. Data indicate mean \pm SEM of the number of Fos-labeled profiles per section (42-50 sections from three animals of each time point). $*$ Significant difference $(p<0.01, t$ test) between lesioned and sham-operated groups.

tion. Although SPir in laminae III-IV of the spinal cord (Fig. $5 B$ ) showed a small increase 2 weeks after axotomy, this increase was not significant compared to the sham-operated animals. In the gracile nucleus, there was a significant increase in SPir on the lesioned side, as compared with the contralateral side, 2 wecks after sciatic nerve transection (Figs. 4C,D). Figure $5 A$ shows the time course of increase in SPir in the gracile nucleus, which peaked 2 weeks after axotomy. PPT mRNA expression in medium- to large-sized DRG neurons, which was first detectable a few days after spinal nerve transection and peaked around 7-10 d (unpublished observation), precedes the increase in SPir in the gracile nucleus.

\section{Fos expression after electrical stimulation}

Fos expression in the gracile nucleus was detectable only on the lesioned side (Fig. 6B) when electrical stimuli at $\Lambda \beta$ fiber strength $(0.1 \mathrm{~mA})$ were delivered bilaterally to the sciatic nerves, as has been shown previously (Molander et al., 1992; Persson et al., 1993). No or very few Fos-labeled nuclei were found in the gracile nucleus contralateral to the axotomy (Fig. 6A). There 

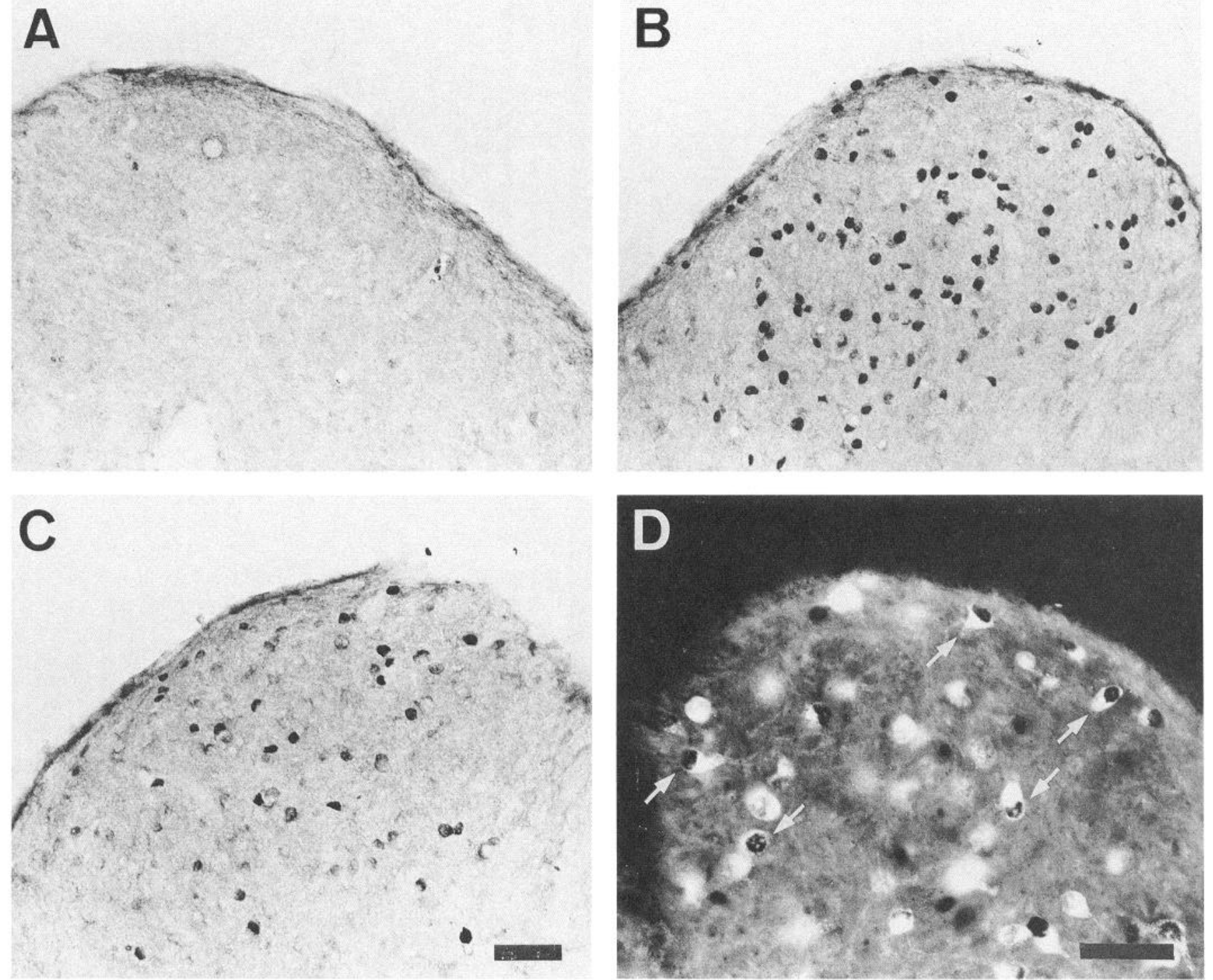

Figure 6. $A$ and $B$, Photomicrographs of the gracile nucleus showing Fos expression induced by bilateral electrical stimulation (0.1 mA) of the sciatic nerve $14 \mathrm{~d}$ after unilateral transection. Note that the gracile nucleus expressed a number of Fos-labeled profiles only on the lesioned side $(B)$, while very few profiles were visible on the contralateral side $(A)$. $C$, Effect of periodic injections of CP-96,345 (5 mg/kg, s.c.; Pfizer) on Fos expression in the gracile nucleus after electrical stimulation of the injured sciatic nerve. Note that Fos expression in the gracile nucleus of rats treated with CP-96,345 was suppressed, as compared with that in untreated rats $(B)$. $D$, Fluorescent photomicrograph showing Fos-labeled gracile neurons projecting to the thalamic VPL nucleus. Note that a number of gracile neurons contain Fos in the nucleus and Fluorogold in the cytoplasm (arrows). Scale bars $(A-D), 50 \mu \mathrm{m}$.

were few Fos-labeled nuclei in the gracile nucleus ipsilateral to the axotomy without electrical stimulation. One day after sciatic nerve transection, electrical stimulation $(0.1 \mathrm{~mA})$ induced an increase in the number of Fos-labeled profiles $(17.6 \pm 1.2$ per section) in the ipsilateral gracile nucleus. The time course (Fig. $5 C$ ) of the number of Fos-labeled profiles in the gracile nucleus peaked at 2 weeks after operation $(81.7 \pm 1.9$ per section). Although there was an uneven labeling of SPir and Fos in the gracile nucleus among sections, the overall distributions of both labels were very similar and corresponded to the sciatic terminal area (Willis and Coggeshall, 1991). For both substances, the most intense and frequently observed labeling was in the dorsal part of the nucleus at the level of the obex.

A double-labeling study for Fos expression in the gracile nucleus, in which neurons projecting to the ventral posterior lateral nucleus (VPL) of the contralateral thalamus were labeled in advance with Fluorogold, revealed that $45.5 \pm 1.3 \%$ of Fos-labeled cells also contained Fluorogold (Fig. $6 D, n=28$ sections from three animals).

In laminae III-IV of the spinal cord, an increased number of Fos-labeled nuclei was found on the side ipsilateral to the axotomy, which is consistent with a previous report (Molander et al., 1992). The time course (Fig. 5D) of the number of Foslabeled nuclei was similar to the increase in the gracile nucleus (Fig. 5C).

\section{NK-1 receptor antagonist}

In animals that received a single injection of CP-96,345 $(5 \mathrm{mg} /$ $\mathrm{kg}$, s.c.) $30 \mathrm{~min}$ before electrical stimulation to the injured sciatic nerve, the number of Fos-labeled profiles per section $(n=49$ 
52 sections from three animals in each group) showed a small (10-12\%) but statistically significant decrease, as compared with those in control (saline-injected) animals. Treatment with CP96,344 induced no decrease of Fos expression (Fig. 7A).

In animals receiving periodic injections of CP-96,345, the number of Fos-labeled profiles was reduced dose dependently (Figs. $6 C$ and $7 B$ ); $20 \%$ decrease for $2 \mathrm{mg} / \mathrm{kg}$ and $33 \%$ decrease for $5 \mathrm{mg} / \mathrm{kg}$ compared to control rats. The same dose of CP$96,344(5 \mathrm{mg} / \mathrm{kg}$ ) showed no effect (Fig. 7B).

\section{Substance $P$ receptor in the gracile nucleus}

A postsynaptic effect of SP in the gracile nucleus would require the existence of substance $P$ receptors. Immunohistochemical examination using a polyclonal SPR antibody revealed that there are moderately labeled fibers and cell bodies (Fig. 8A,B), consistent with previous findings (Nakaya et al., 1994). One or 2 weeks after axotomy, some sections showed a small decrease in SPRir in the gracile nucleus, but this decrease was not significant compared to the sham-operated animals (Fig. 8C).

\section{Discussion}

De novo expression of PPT $m R N A$

In a previous report (Noguchi et al., 1994), we demonstrated by in situ hybridization that peripheral axotomy of lumbar DRG neurons results in the appearance of PPT mRNA. We also showed that substance $P$ innmunoreactivity appeared in a subpopulation of medium- to large-sized DRG neurons. The present experiments confirmed both of these observations, and in addition, showed the presence of SP in large myelinated dorsal root axons after peripheral nerve transection. Spinal nerve transection, which axotomizes almost all the ganglion's neurons, produced more labeling of large-sized cells than did sciatic nerve transection, which axotomizes roughly one-half of the ganglion's neurons.

Cells double labeled with Fluorogold and PPT mRN $\Lambda$ were very rare or absent in control and contralateral DRGs. We thus conclude that double-labeled cells seen after peripheral axotomy are displaying de novo expression of PPT mRNA. Our findings suggest that the expression of the PPT gene is differentially regulated in subpopulations of DRG neurons after peripheral axotomy: repression in small cells and induction in medium to large cells. The mechanism of differential regulation of the PPT gene is obscure. However, it is known that the expression of tachykinin peptides is regulated by several transcription factors (I indsay and Harmar, 1989; Nawa and Patterson, 1990), which may affect different DNA elements in the promoter region of the PPT gene (Kageyama et al., 1991).

\section{Increase in substance $P$ immunoreactivity}

Immunoelectronhistochemistry revealed that large-sized myelinated fibers in L5 dorsal root contained SPir only on the side ipsilateral to the L5 spinal nerve transection. This shows that newly synthesized SP in large DRG cells is transported, via large myelinated fibers, toward the CNS.

We observed increased SPir in the gracile nucleus, which is consistent with the de novo synthesis and transport of PPI gene product from medium to large DRG cells. The time course of increase in SPir in the gracile nuclcus, which followed the induction of PPT mRNA in DRG cells, peaked at 2 weeks after axotomy and was significantly increased for at least 4 weeks. We note that the level of increase in SPir was less than that of another upregulated neuropeptide, neuropeptide Y (NPY) (Wak-

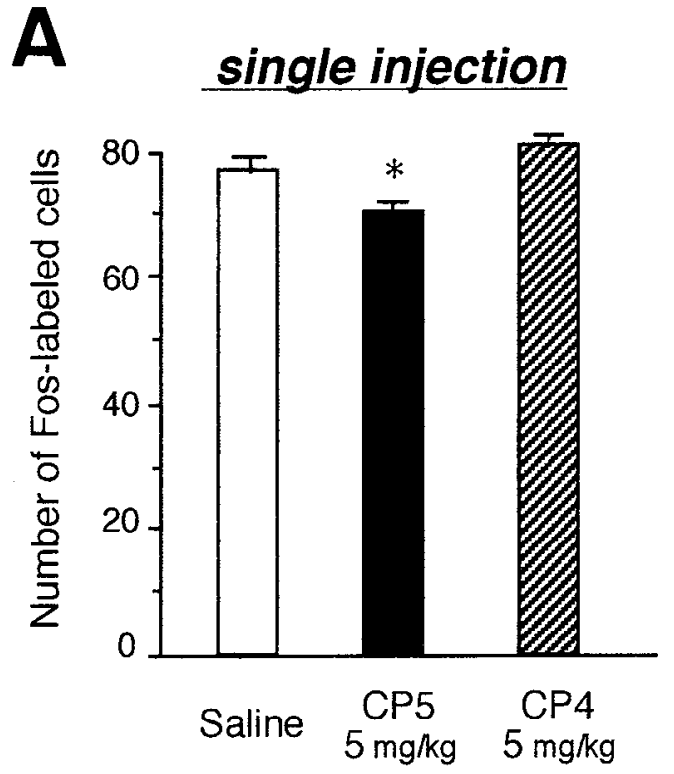

B

\section{periodic injections}

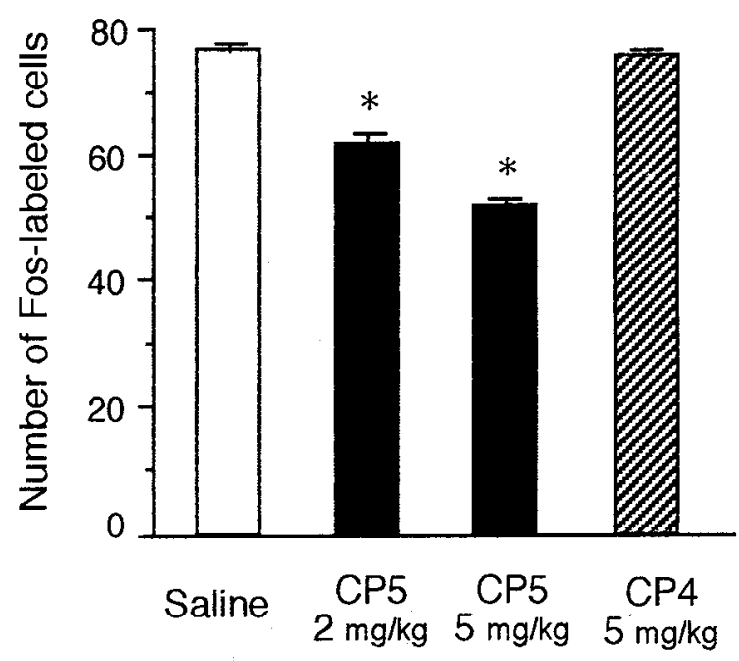

Figure 7. $A$ and $B$, Effect of single $(A)$ and periodic $(B)$ injections of CP-96,345 (CP5) or CP-96,344 (CP4) (2 or $5 \mathrm{mg} / \mathrm{kg}$, s.c.) on Fos expression in the gracile nucleus. Animals received electrical stimulation $(0.1 \mathrm{~mA})$ to the injured sciatic nerve $7 \mathrm{~d}$ after operation. In the periodic injection group $(B)$, the compounds were given every $12 \mathrm{hr}$ for 1 week. Data are the mean \pm SEM of the number of Fos-labeled profiles per section $(n-45-48$ sections from three animals in each group). *Significant difference $(p<0.01)$ between experimental and control groups.

isaka et al., 1991; Zhang et al., 1993). It may be that the number of DRG cells expressing PPT mRNA after peripheral axotomy are much fewer than that expressing NPY mRNA (Noguchi et al., 1993; Zhang et al., 1993). It is unclear whether there is a population of DRG cells that expresses both PPT and NPY mRNAs.

The lack of a significant increase in SPir in laminae III-IV of the spinal cord, the terminal region for large myelinated afferents, is inconsistent with our observations in the ganglia, dorsal roots, and gracile nucleus. Although about one-third of sections 

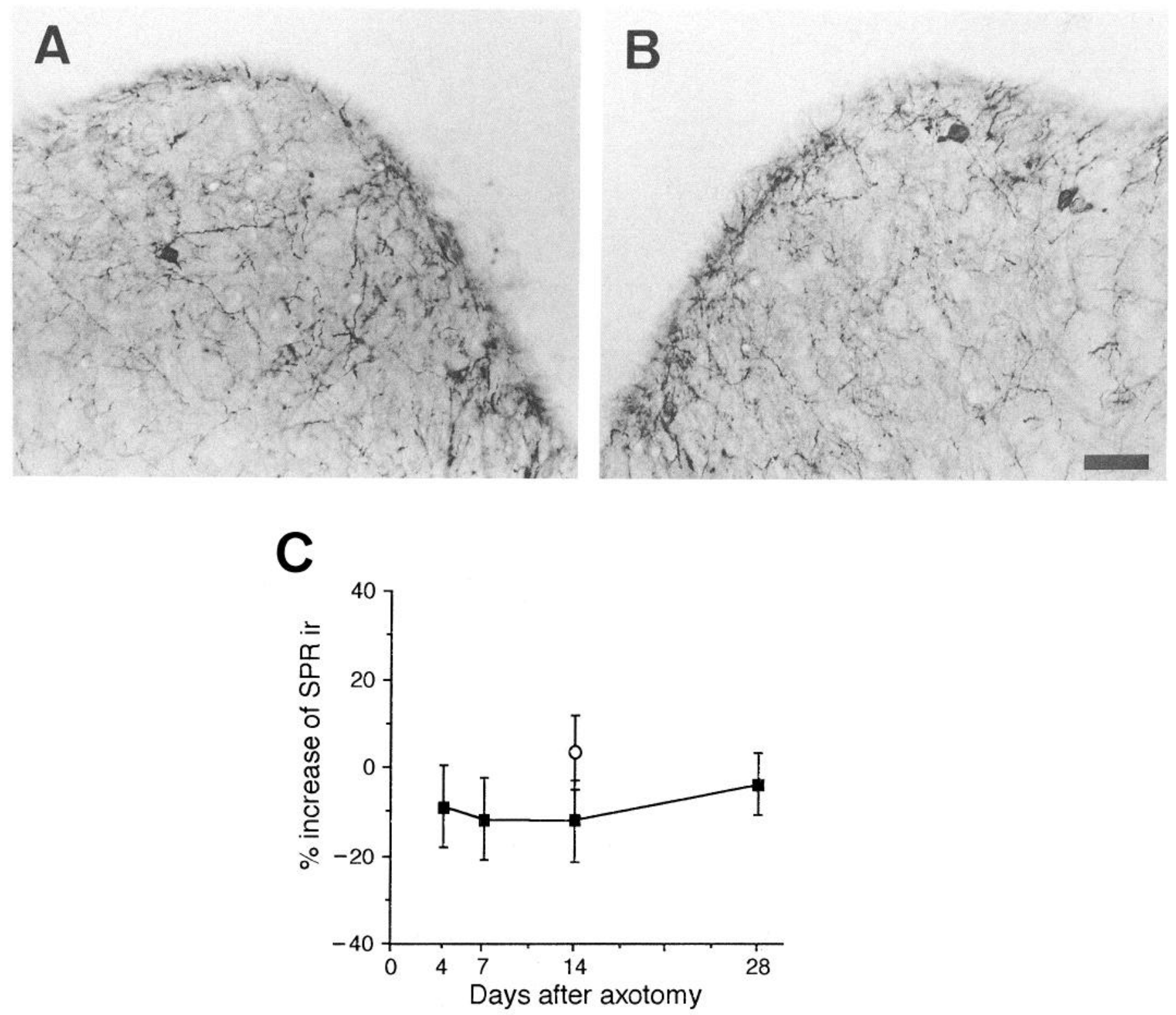

Figure 8. $A$ and $B$, Photomicrographs showing substance P receptor immunoreactivity (SPRir) in the gracile nucleus contralateral $(A)$ and ipsilateral $(B)$ to the axotomy. Animals received a unilateral transection of the sciatic nerve $7 \mathrm{~d}$ previously. Scale bar, $50 \mu \mathrm{m}$. $C$, Time course of the change in SPRir in the ipsilateral gracile nucleus after unilateral transection of the sciatic nerve (squares) or a sham operation (circle). The percent change is the ratio of SPRir in the ipsilateral side relative to the contralateral side. Data are the mean \pm SEM (28-32 sections from three animals at each time point).

showed a small increase in SPir in the medial parts of lamina III-IV ipsilateral to axotomy, this increase was neither consistent nor statistically significant. One possible explanation is that the increase is small relative to the normal SPir labeling in laminae III-IV, so that the SP derived from the de novo expression in the DRG was undetectable. Divergent terminations of central branches of lumbar DRG cells into the multiple levels of the spinal cord (Willis and Coggeshall, 1991) as well as the scarcity of PPT mRNA expressing cells after axotomy (this study), might also account for the lack of a detectable increase in dorsal horn SPir. An alternative explanation is that the DRG neurons expressing SP after axotomy send branches only to the gracile nucleus and not to the spinal cord. However, there has been no report in the literature suggesting the existence of such DRG neurons.

\section{Fos expression and increased SP in gracile nucleus}

Gracile nucleus neurons expressed c-fos protein after electrical stimulation of the previously injured sciatic nerve (Molander et al., 1992; Persson et al., 1993). Intense stimulation (C-fiber strength) of normal sciatic nerve is not able to induce c-fos in the gracile nucleus. We examined the time course (interval from sciatic nerve transection and electrical stimulation) of c-fos expression in the gracile nucleus, and found a small number of c-fos-labeled profiles a few days after axotomy and a peak response at 2 weeks after axotomy (Fig. 5C).

The SP released by large DRG neurons may affect the excitability and gene expression of postsynaptic neurons in spinal cord and gracile nucleus via cooperative actions with glutamate (Kangrga and Randic, 1990; Haley and Wilcox, 1992) or by 
activating phospholipase $\mathrm{C}$ activity (Yokota et al., 1989). Using the NK-1 antagonist, CP-96,345, SP has been shown to mediate a prolonged excitation of nociceptive neurons in the dorsal horn following noxious peripheral stimulation (De Koninck and Henry, 1991). The induction of c-fos in the gracile nucleus by electrical stimulation of the injured nerve may be derived from an increased release of SP as a result of sustained activation of SPcontaining large myelinated fibers. Parallel time courses for the increase in SPir (Fig. 5A) and the number of Fos-labeled nuclei (Fig. $5 C$ ) also suggest a possible relationship between increased SP and activation of gracile nucleus neurons. The existence of SP receptor in the gracile nucleus (Figs. $8 A, B$ ) (Nakaya et al., 1994 ) is consistent with this idea.

\section{NK-1 receptor antagonist and $c$-fos expression}

To verify the hypothesis mentioned above, the effect of an NK-1 antagonist on the stimulus-induced $c$-fos expression in the gracile nucleus was examined. $c$-fos expression has been established as a marker of cellular activation (Hunt et al., 1987; Menetrey et al., 1989; Morgan and Curran, 1989; Bullitt, 1990). A single injection of CP-96,345 at $5 \mathrm{mg} / \mathrm{kg} 30 \mathrm{~min}$ before electrical stimulation reduced significantly the number of c-fos-labeled profiles in the gracile nucleus. Periodic injections of CP-96,345 $30 \mathrm{~min}$ before surgery and every $12 \mathrm{hr}$ for 1 week further reduced c-fos expression.

The affinity of NK-1 receptor antagonists exhibits marked differences between species (Beresford et al., 1991; Gitter et al., 1991, Snider et al., 1991). CP-96,345 has 100-fold higher affinity for NK-1 receptor sites in bovine, guinea pig, and human tissue, compared to rat or mouse. Moreover, $\mathrm{CP}$ compounds are known to interact with L-type calcium channels at relatively low concentrations; and this may complicate the interpretation of experimental results, particularly in rat or mouse (Schmidt et al., 1992; Guard et al., 1993). However, CP-96,345 and its enantiomer, CP-96,344, have the same affinity for the $\mathrm{Ca}^{2+}$ channel, but CP-96,344 has no effect on the NK-1 receptor. Thus, when a dose of CP-96,345 is effective and the same dose of CP-96,344 is not, it is reasonable to conclude that the effect mediated through NK-1 receptor activity (Lembeck et al., 1992; Yashpal et al., 1993). In this study, CP-96,344 had no effecl, at 5 Ing/kg s.c., on c-fos expression. Our preliminary study revealed that 5 $\mathrm{mg} / \mathrm{kg}$ s.c. is close to the maximal dose, beyond which CP96,344 showed an inhibitory effect on c-fos expression in the gracile nucleus.

\section{Functional significance}

Peripheral nerve injury is known to trigger hyperexcitability in neurons in the DRG-dorsal horn-thalamic pathway that transmits information about noxious stimuli (Wall and Devor, 1983; Guilbaud et al., 1990; Seltzer et al., 1991; Palecek et al., 1992; Woolf, 1992; Laird and Bennett, 1993). In the normal case, the sensory pathway from large myelinated primary afferents through the dorsal column nuclei to the thalamus is primarily involved in the transmission of information about tactile stimuli (Willis and Coggeshall, 1991). However, information originating in nociceptors can reach the thalamus via the spinal cord's postsynaptic dorsal column neurons (e.g., Ferrington, 1988; Cliffer et al., 1992)

Our data indicate that SP is synthesized in injured DRG neurons and contributes to hyperexcitability of neurons and changes in gene expression in gracile nucleus neurons, including those that project to the thalamus. It is probable that the effects seen in the gracile nucleus are directly related to activity in large myelinated primary afferents that express SPir after nerve injury and ascend the dorsal columns. However, we cannot discount a contribution from an indirect source-increased input to the gracile nucleus from intrinsic dorsal horn projection neurons (e.g., the postsynaptic dorsal column system; Cliffer and Giesler, 1989). Recent work (J Brown et al., 1993, Soc Neurosci Abstr) shows that sciatic nerve transection increases $\mathrm{NK}-1$ receptor immunoreactivity in the spinal gray matter, suggesting that de novo input from SP-containing primary afferents might evoke a greater than normal response in spinal neurons. As shown here, the increase in Fos expression in laminae III-IV after electrical stimulation of the injured peripheral nerve also suggests an elevated sensitivity of spinal neurons. It is important to note that these results do not imply that it is only SP in primary afferent neurons that is involved in regulation of postnerve injury changes in excitability in the dorsal column pathway.

The changes in excitability of gracile nucleus neurons is very likely to affect the activity of neurons in the thalamus and somatosensory cortex (Guilbaud et al., 1990), so that de novo SP in damaged primary afferent neurons may contribute to abnormal neuropathic sensations, e.g., dysesthesiae and mechano-allodynia (Baron and Maier, 1995).

\section{References}

Baranowsli AP, Priestley JV, McMahon S (1993) Substance P in cutaneous primary sensory neurons-a comparison of models of nerve injury that allow varying degrees of regeneration. Neuroscience 55: $1025-1036$.

Baron R, Maier C (1995) Phantom limb pain: are cutaneous nociceptors and spinothalamic neurons involved in the signaling and maintenance of spontaneous and touch-evoked pain? A case report. Pain 60:223-2228.

Basbaum AI, Chi S-I, Levine JD (1992) Peripheral and central contribution to the persistent expression of the c-fos proto-oncogene in spinal cord after peripheral nerve injury. In: Hyperalgesia and allodynia (Willis WD, ed), pp 295-304. New York: Raven.

Beresford IJM, Birch PJ, Hagan RM, Ireland SJ (1991) Investigation into species variants in tachykinin NK1 receptors by use of the nonpeptide antagonist, CP-96,345. Br J Pharmacol 104:292-293.

Brown AG (1981) Organization in the spinal cord. Heiderberg: Springer.

Bullitt EJ (1990) Expression of c-Fos-like protein as a marker for neuronal activity following noxious stimulation in the rat. J Comp Neurol 296:517-530.

Cliffer KD, Giesler GJ (1989) Postsynaptic dorsal column pathway of the rat: III. Distribution of ascending afferent fibers. J Neurosci 9:3146-3168

Cliffer KD, Hasegawa T, Willis WD (1992) Responses of neurons in the gracile nucleus of cats to innocuous and noxious stimuli: basic characterization and antidromic activation from the thalamus. J Neurophysiol 68:818-832.

Coderre TJ, Katz J, Vaccarino AL, Melzack R (1993) Contribution of central neuroplasticity to pathological pain: review of clinical and experimental evidence. Pain 52:259-285.

De Koninck Y, Henry JL (1991) Substance P-mediated slow excitatory postsynaptic potential elicited in dorsal horn neurons in vivo by noxious stimulation. Proc Natl Acad Sci USA 88:11344-11348.

Ferrington DG, Downie JW, Willis WD (1988) Primate nucleus gracilis neurons: responses to innocuous and noxious stimuli. J Neurophysiol 59:886-907.

Gitter BD, Waters DC, Bruns RF, Mason NR, Nixon JA, Howbert JJ (1991) Species differences in affinities of non-peptide antagonists for substance P receptors. Eur J Pharmacol 197:237-238.

Gracely RH, Lynch SA, Bennett GJ (1992) Painful neuropathy: altered central processing maintained dynamically by peripheral input. Pain 51:175-194.

Guard S, Boyle SJ, Tang K-W, Watling KJ, McKnight AT, Woodruff GN (1993) The interaction of the NK1 receptor antagonist CP- 
96,345 with L-type calcium chammels and its functional consequences. Br J Pharmacol 110:385-391.

Guilbaud G, Benoist LM, Jazat F, Gautron M (1990) Neuronal responsiveness in the ventrobasal thalamic complex of rats with an experimental peripheral mononeuropathy. J Neurophysiol 64:1537-1554.

Haley JE, Wilcox GL (1992) Involvement of excitatory amino acids and peptides in the spinal mechanisms underlying hyperalgesia. In: Hyperalgesia and allodynia (Willis WD, ed), pp 281-293. New York: Raven.

Henken DB, Battisti WP, Chesselet MF, Murray M, Tessler A (1990) Expression of $\beta$-preprotachykinin mRNA and tachykinins in rat dorsal root ganglion cells following peripheral or central axotomy. Neuroscience 39:733-742.

Hökfelt T, Wiesenfeld-Hallin X, Villar MJ, Melander T (1987) Increase of galanin-like immunoreactivity in rat dorsal root ganglion cells after peripheral axotomy. Neurosci Lett 83:217-220.

Hökfelt T, Zhang X, Wiesenfeld-Hallin Z (1994) Messenger plasticity in primary sensory neurons following axotomy and its functional implications. Trens Neurosci 17:22-30.

Hunt SP, Pini A, Fvan G (1987) Induction of c-Fos-like protein in spinal cord neurons following sensory stimulation. Nature 328, 632634.

Jessell T, Tsunoo A, Kanazawa I, Otsuka M (1979) Substance P: depletion in the dorsal horn of the rat spinal cord after section of the peripheral processes of primary sensory neurons. Brain Res 168:247259.

Kageyama R, Sasai Y, Nakanishi S (1991) Molecular characterization of transcription factors that bind to the cAMP responsive region of the substance $\mathrm{P}$ precursor gene. J Biol Chem 266:15525-15531.

Kangrga I, Randic M (1990) Tachykinins and calcitonin gene-related peptide enhance release of endogenous glutamate and aspartate form the rat spinal dorsal horn slice. J Neurosci 10:2026-2038.

Krause JE, Chirgwin JM, Carter MS, Xu ZS, Hershey AD (1987) Three rat prepro-tachykinin mRNAs encode the neuropeptides substance $P$ and neurokinin A. Proc Natl Acad Sci USA 84:881-885.

Laird JMA, Bennett GJ (1993) An electrophysiological study of dorsal horn neurons in the spinal cord of rats with an experimental peripheral neuropathy. J Neurophysiol 69:2072-2085.

Lembeck F, Donnerer J, Tsuchiya M, Nagahisa A (1992) The nonpeptide tachykinin antagonist, CP-96,345, is a potent inhibitor of neurogenic inflammation. Br J Pharmacol 105:527-530.

Levine JD, Fields HL, Basbaum AI (1993) Peptides and the primary afferent nociceptor. J Neurosci 13:2273-2286.

Lindsay RM, Harmar AJ (1989) Nerve growth factor regulates expression of neuropeptide genes in adult sensory neurons. Nature 337 : 362-364.

Menetrey D, Gannon A, Levine JD, Basbaum AI (1989) Expression of $\mathrm{c}$-Fos protein in interneurons and projection neurons of the rat spinal cord in response to noxious somatic, articular, and visceral stimulation. J Comp Neurol 285:177-195.

Molander C, Hongpaisan J, Grant G (1992) Changing pattern of c-fos expression in spinal cord neurons after electrical stimulation of the chronically injured sciatic nerve in the rat. Neuroscience 50:223-236.

Morgan JI, Curran T (1989) Stimulus-transcription coupling in neurons: role of cellular immediate-early genes. Trens Neurosci 12:459462.

Nakaya Y, Kaneko T, Shigemoto R, Nakanishi S, Mizuno N (1994) Immunohistochemical localization of substance $\mathrm{P}$ receptor in the central nervous system of the adult rat. J Comp Neurol 347:249-274.

Nawa H, Patterson PH (1990) Separation and partial characterization of neuropeptide-inducing factors in heart cell conditioned medium. Neuron 4:269-277.

Nielsch V, Bisby MA, Keen P (1987) Effect of cutting or crushing the rat sciatic nerve on synthesis of substance $\mathrm{P}$ by isolated $\mathrm{L} 5$ dorsal root ganglia. Neuropeptides 10:137-145.

Noguchi K, Ruda MA (1992) Gene regulation in an ascending nociceptive pathway: inflammation-induced increase in preprotachykinin mRNA in rat lamina I spinal projection neurons. J Neurosci 12:25632572.

Noguchi K, Senba E, Morita Y, Sato M, Tohyama M (1989) PreproVIP and preprotachykinin mRNAs in the rat dorsal root ganglion cells following peripheral axotomy. Mol Brain Res 6:327-330.

Noguchi K, Senba E, Morita Y, Sato M, Tohyama M (1990) $\alpha$-CGRP and $\beta$-CGRP InRNAs are differentially regulated in the rat spinal cord and dorsal root ganglion. Mol Brain Res 7:299-304.

Noguchi K, De Leon M, Nahin RL, Senba E, Ruda MA (1993) Quantification of axotomy-induced alteration of neuropeptide mRNAs in dorsal root ganglion neurons with special reference to neuropeptide $Y$ mRNA and the effects of neonatal capsaicin treatment. J Neurosci Res 35:54-66.

Noguchi K, Dubner R, DeLeon M, Senba E, Ruda MA (1994) Axotomy induces preprotachykinin gene expression in a subpopulation of dorsal root ganglion neurons. J Neurosci Res 37:596-603.

Palecek J, Palecckova V, Dougherty PM, Carlton SM, Willis WD (1992) Responses of spinothalamic tract cells to mechanical and thermal stimulation of skin in rats with experimental peripheral neuropathy. J Neurophysiol 67:1562-1573.

Persson JKE, Hongpaisa $\mathbf{J}$, Molander C (1993) c-fos expression in gracilothalamic tract neurons after electrical stimulation of the injured sciatic nerve in the adult rat. Somatosens Res 10:475-483.

Schnirdt AW, McLean S, Heym J (1992) The substance P receptor antagonist CP-96,345 interacts with $\mathrm{Ca}^{2+}$ channels. Eur J Pharmacol 215:351-352.

Seltzer Z, Beilin BZ, Ginzburg R, Paran Y, Shimko T (1991) The role of injury discharge in the induction of neuropathic pain behavior in rats. Pain 46:327-336.

Shehab SA, Atkinson ME (1986) Vasoactive intestinal polypeptide (VIP) increases in the spinal cord after peripheral axotomy of the sciatic nerve originate from primary afferent neurons. Brain Res 372 : $37-44$.

Snider RM, Constantine JW, Lowe JA III, Longo KP, Lebel WS, Woody HA, Drozda SE, Desai MC, Vinick FJ, Spencer RW, Hess H-J (1991) A potent nonpeptide antagonist of the substance $\mathrm{P}$ (NK1) receptor Science 251:435-437.

Thompson SWN, Dray A, Urban L (1994) Injury-induced plasticity of spinal reflex activity: NK1 neurokinin receptor activation and enhanced A- and C-fiber mediated responses in the rat spinal cord in vitro. J Neurosci 14:3672-3687.

Villar MJ, Cortes R, Theodorsson E (1989) Neuropeptide expression in rat dorsal root ganglion cells and spinal cord after peripheral nerve injury with special reference to galanin. Neuroscience 33:587-604.

Wakisaka S, Kajander KC, Bennett GJ (1991) Increased neuropeptide (NPY)-like immunoreactivity in rat sensory neurons following peripheral axotomy. Neurosci Lett 124:200-203.

Wakisaka S, Kajander KC, Bennett GJ (1992) Effects of peripheral nerve injuries and tissue inflammation on the levels of neuropeptide Y-like immunoreactivity in rat primary afferent neurons. Brain Res 598:349-352.

Wall PD, Devor M (1983) Sensory afferent impulses originates from dorsal root ganglia as well as from the periphery in normal and nerve injured rats. Pain 17:321-339.

Wiesenfeld-Hallin Z, Hao J-X, Xu X-J, Hökfelt T (1993) Nitric oxide mediates ongoing discharges in dorsal root ganglion cells after peripheral nerve injury. J Neurophysiol 70:2350-2353.

Willis WD, Coggeshall RE (1991) Sensory mechanisms of the spinal cord. New York: Plenum.

Woolf CJ (1983) Evidence for a central component of post-injury pain hypersensitivity. Nature 306:686-688.

Woolf CJ (1992) Excitability changes in central neurons following peripheral damage: role of central sensitization in the pathogenesis of pain. In: Hyperalgesia and allodynia (Willis WD, ed), pp 221-244. New York: Raven.

Woolf CJ, Shortland P, Coggeshall RE (1992) Peripheral nerve injury triggers central s sprouting of myelinated afferents. Nature 355:7578.

Yashpal K, Radhakrishnan V, Coderre TJ, Henry JL (1993) CP-96,345, but not its stereoisomer, CP-96,344, blocks the nociceptive responses to intrathecally administered substance $\mathrm{P}$ and to noxious thermal and chemical stimuli in the rat. Neuroscience 52:1039-1047

Yokota Y, Sasai Y, Tanaka K, Fujiwara T, Tsuchida K, Shigemoto R, Kakizuka A, Ohkubo H, Nakanishi S (1989) Molecular characterization of a functional cDNA for rat substance $\mathrm{P}$ receptor. J Biol Chem 264:17649-17652.

Zhang X, Meister B, Elde R, Verge VMK, Hökfelt T (1993) Large calibre primary afferent neurons projecting to the gracile nucleus express neuropeptide $\mathrm{Y}$ after sciatic nerve lesions: an immunohistochemical and in situ hybridization study in rats. Eur J Neurosci 5:1510-1519. 